\title{
Maternal gene polymorphisms involved in folate metabolism and risk of Down syndrome offspring: a meta-analysis
}

\author{
Elias Zintzaras
}

Received: 4 August 2007/Accepted: 19 September 2007/Published online: 13 October 2007

(C) The Japan Society of Human Genetics and Springer 2007

\begin{abstract}
Studies investigating the association between gene polymorphisms involved in homocysteine/folate metabolism and Down syndrome (DS) have reported contradictory or inconclusive results. A meta-analysis of 11 case-control studies relating MTHFR C677T, MTHFR A1298C and MTRR A66G gene polymorphisms to the maternal risk of DS was carried out. For MTHFR C677T polymorphism the heterogeneity between studies was significant $(P=0.03)$ and the random effects $(\mathrm{RE})$ pooled odds ratio (OR) was not significant: $\mathrm{RE} \mathrm{OR}=1.18(0.99$ 1.40). The recessive model for allele MTHFR 677T showed nonsignificant heterogeneity overall $(P=0.21)$ and the association was not significant: fixed effects (FE) $\mathrm{OR}=1.27 \quad(0.98-1.64)$. However, sensitivity analysis changed the pattern of results and the association became marginally significant $[\mathrm{FE}$ OR $=1.31(1.01-1.71)]$. The dominant model showed no association. Finally, statistically significant associations between the MTHFR A1298C and MTRR A66G gene polymorphisms and the risk of DS were not found. The cumulative meta-analysis of MTHFR C677T showed a trend toward an association as the amount of data increased, and the recursive cumulative metaanalysis indicated that there was insufficient evidence for
\end{abstract}

E. Zintzaras $(\bowtie)$

Department of Biomathematics,

University of Thessaly School of Medicine,

Papakyriazi 22, Larissa 41222, Greece

e-mail: zintza@med.uth.gr

E. Zintzaras

Center for Clinical Evidence Synthesis,

Institute for Clinical Research and Health Policy Studies,

Tufts-New England Medical Center,

Tufts University School of Medicine,

Boston, MA, USA claiming or denying an association for all gene polymorphisms. In addition, there was no difference between the magnitude of effect observed in large versus small studies. Large and rigorous case-control studies that investigate gene-gene and gene-environment interactions need to be performed before conclusive claims about the genetics of DS can be made.

Keywords Down syndrome - MTHFR - MTRR . Gene $\cdot$ Polymorphism $\cdot$ Meta-analysis

\section{Introduction}

Down syndrome (DS) or trisomy 21 is a genetic disorder attributed to the presence and expression of three copies of genes located on chromosome 21 , which is mainly due to abnormal segregation during meiosis (maternal nondisjunction in 90\% of cases) (Antonarakis et al. 1992; Hassold and Jacobs 1984; James 2004). The mechanism underlying the meiotic nondisjunction is poorly understood and is thought to have a multifactorial aetiology, being influenced by both genetic and acquired factors (James et al. 1999; Martinez-Frias et al. 2006).

Abnormal folate metabolism and common folate-metabolizing enzyme variants have been described as being possible risk factors for DS (James et al. 1999; Hobbs et al. 2000). A dietary folate and methyl donor deficiency results in DNA hypomethylation, DNA strand breaks and abnormal chromosome segregation (Blount et al. 1997; Hobbs et al. 2002). Two critical folate-metabolizing enzyme variants involved in the folate/homocysteine metabolic pathway are 5-10 methylenetetrahydrofolate reductase (MTHFR) and methionine synthase reductase (MTRR). MTHFR catalyzes the irreversible conversion of 5,10-methylenetetrahydrofolate 
to 5-methyltetrahydrofolate and directs the flux of intracellular folate toward the conversion of homocysteine to methionine at the expense of nucleotide synthesis (Ueland et al. 2001). Folate deficiency has been shown to induce DNA damage through uracil misincorporation into DNA during replication, leading to an increased risk of DNA doublestrand breaks during DNA excision repair and subsequent genetic instability (Blount et al. 1997). MTHFR C677T and A1298C are two common polymorphisms that have been described for this enzyme (Frosst et al. 1995; Weisberg et al. 1998) and these have been associated with different disorders/ diseases (Zintzaras et al. 2005, 2006a, 2007; Zintzaras 2006a, 2006b, 2006c). MTRR maintains the methionine synthase enzyme at an active stage for the remethylation of homocysteine to methionine (Hobbs et al. 2000). MTRR A66G is a polymorphism in the MTRR gene which was recently associated with increased risk of spina bifida (Wilson et al. 1999). This polymorphism might be a genetic risk factor for DS since the methionine synthase reaction is important in maintaining normal folate metabolism and DNA methylation. Hassold and Jacobs (1984) have investigated the association between MTHFR C677T and MTRR A66G gene polymorphisms and other human trisomies such as trisomy 18 and trisomy 13, and they have provided evidence that MTHFR is associated with trisomy 18 , but they were unable to identify any other significant associations.

Case-control studies that have investigated the association between DS mothers and MTHFR C677T, MTHFR A1298C and MTRR A66G polymorphisms have provided controversial or inconclusive results, partly because each study involved small numbers of cases and controls, and so there was not enough information to demonstrate association. Furthermore, data interpretation was complicated by the fact that different populations and sampling strategies were used. In order to shed some light on these contradictory results, as well as to decrease the uncertainty in the effect size of the risk, a meta-analysis (Whitehead 2002) of all available studies relating the MTHFR C677T, MTHFR A1298C and MTRR A66G gene polymorphisms with maternal risk for DS was carried out. In addition, the heterogeneity between studies and the existence of potential bias were explored. Cumulative and recursive cumulative meta-analyses were also performed (Lau et al. 1992).

\section{Materials and methods}

Selection of studies

Studies were identified by searching the PubMed database for relevant articles in English published before April 2007 using the following criterion: (methylenetetrahydrofolate reductase or MTHFR or C677T or A1298C or methionine synthase reductase or MTRR or A66G) and (Down syndrome or Trisomy 21). The retrieved articles were read in their entirety to assess their appropriateness for inclusion in the meta-analysis. All references cited in the articles were also reviewed to identify additional published work not indexed by the PubMed database. Case reports, editorials and review articles were excluded.

Case-control studies that determined the distributions of the MTHFR C677T, MTHFR A1298C and MTRR A66G genotypes in case mothers and in a control group of mothers were eligible for inclusion in the meta-analysis. Case mothers are considered mothers that gave birth to at least one child with DS, and the controls are mothers that have given birth to children without reported abnormalities. Only studies in human subjects that have used validated genotyping methods were considered. Family-based association studies were not considered because of different design considerations.

\section{Data extraction}

The following information was extracted from each study: first author, journal, year of publication, "race" of study population, demographics, matching, genotyping method, and the number of cases and controls for the MTHFR C677T, MTHFR A1298C and MTRR A66G genotypes. The allele frequencies were calculated, for cases and controls, from the corresponding genotype distributions. In addition, whether the genotypic data were read blind in terms of the case-control status was also recorded. When studies investigated more than one polymorphism, information on combined genotype estimation was recorded.

\section{Meta-analysis}

The meta-analysis examined the association between each gene polymorphism and DS for the allele contrast, and the recessive and dominant models of the mutant allele. The associations were indicated as a pooled odds ratio (OR) with the corresponding $95 \%$ confidence interval (CI). The heterogeneity between studies was tested using the $Q$-statistic, which is a weighted sum of the squares of the deviations of individual study OR estimates from the overall estimate (Cochran 1954). When the ORs are homogeneous, $Q$ follows a chi-squared distribution with $r-1$ ( $r$ is the number of studies) degrees of freedom $(d f)$. When $P<0.10$ then the heterogeneity was considered to be statistically significant. Heterogeneity was quantified with the $I^{2}$ metric $\left(I^{2}=(Q-d f) / Q\right)$, which is independent of the number of studies in the meta-analysis. $I^{2}$ takes values of between 0 and $100 \%$, with higher values denoting 
a greater degree of heterogeneity (Zintzaras and Hadjigeorgiou 2004). The pooled OR was estimated using fixed effects (FE) (Mantel-Haenszel) and random effects (RE) (DerSimonian and Laird) models. Random effects modeling assumes a genuine diversity in the results of various studies, and it incorporates a between-study variance into the calculations. Hence, when there is heterogeneity between studies then the pooled OR is preferably estimated using the RE model (Whitehead 2002).

A cumulative and recursive cumulative meta-analysis was carried out for each polymorphism in order to evaluate the trend in the RE OR for the genetic contrast under investigation over time (Lau et al. 1992). In cumulative meta-analysis, studies were chronologically ordered by publication year, and then the pooled ORs were obtained at the end of each year, i.e., at each information step (Zintzaras et al. 2006b; Zintzaras 2007). In recursive cumulative meta-analysis, the relative change in pooled $\mathrm{OR}$ at each information step was calculated. Cumulative and recursive cumulative meta-analysis provide a framework for updating a genetic effect from all studies and a measure of how much the genetic effect changes as evidence accumulates (Zintzaras et al. 2006c). Thus, cumulative meta-analysis indicates the trend in estimated risk effect and recursive cumulative meta-analysis indicates the stability of the risk effect. Different magnitudes of effect in large versus small studies for the allele contrast were checked for using the Egger regression test (Sterne et al. 2000) and the Begg-Mazumdar test, which is based on Kendall's tau (Begg and Mazumdar 1994).

The meta-analysis consisted of the main (overall) analysis, which includes all available data, subgroup analyses by "race," and sensitivity analysis, which examines the effect of excluding specific studies (Zintzaras and Stefanidis 2005; Zintzaras et al. 2006d). The distribution of the genotypes in the control group was tested for HardyWeinberg equilibrium (HWE) using an exact test (Weir 1996). Studies with controls not in HWE or studies that did not report enough information to evaluate the HWE were subjected to a sensitivity analysis (Zintzaras et al. 2006a). Analyses were performed using Meta-Analyst (Joseph Lau, Boston, MA, USA, 1998), and CVF90 with the IMSL library (Kitsios and Zintzaras 2007; Zintzaras and Sakelaridis 2007).

\section{Results}

Eligible studies

The literature review identified 37 titles in PubMed that met the search criteria. The full articles of the retrieved studies were read to assess their appropriateness for meta- analysis. Data from 11 articles that investigated the association between any of the MTHFR C677T, MTHFR A1298C and MTRR A66G gene polymorphisms and DS met the inclusion criteria, and they were included in the meta-analysis. Figure 1 presents a flow chart of the retrieved studies and the studies excluded, with specifying reasons. Eleven studies dealt with MTHFR C677T (James et al. 1999; Hobbs et al. 2000; Stuppia et al. 2002; O'Leary et al. 2002; Boduroglu et al. 2004; Acacio et al. 2005; Chango et al. 2005; da Silva et al. 2005; Rai et al. 2006; Scala et al. 2006; Coppede et al. 2006), seven with MTHFR A1298C (Boduroglu et al. 2004; Acacio et al. 2005; Chango et al. 2005; da Silva et al. 2005; Rai et al. 2006; Scala et al. 2006; Coppede et al. 2006), and five with MTRR A66G (Hobbs et al. 2000; O'Leary et al. 2002; Chango et al. 2005; da Silva et al. 2005; Scala et al. 2006). The studies that investigated MTHFR A1298C or MTRR A66G also investigated MTHFR C677T. Three studies investigated all of the gene polymorphisms together (Chango et al. 2005; da Silva et al. 2005; Scala et al. 2006). The studies were published between 1999 and 2006.

In all studies, validated genotyping methods were used to determine the genetic polymorphisms; namely, PCR and restriction of the PCR product with the enzyme corresponding to each polymorphism (Frosst et al. 1995; Weisberg et al. 1998; Wilson et al. 1999). In three studies, it was stated that the controls were age-matched at conception (Coppede et al. 2006; Stuppia et al. 2002; James et al. 1999). One study provided data by age group (Scala et al. 2006). None of the studies reported the family histories of the DS parents, and only one study (Stuppia et al. 2002) reported that the karyotypes of DS parents were normal.

Studies were conducted in various populations of different "racial" groups: seven involved whites (Coppede et al. 2006; Chango et al. 2005; O'Leary et al. 2002; Scala et al. 2006; Stuppia et al. 2002; Hobbs et al. 2000; James et al. 1999), two mixed Brazilians (da Silva et al. 2005; Acacio et al. 2005), one Indian (Rai et al. 2006), and one Turkish (Boduroglu et al. 2004). A list of the details abstracted from the studies included in the meta-analysis is provided in Table 1 .

\section{Summary statistics}

Overall, the studies provided 1,129/1,489 cases/controls for MTHFR C677T, 746/888 cases/controls for MTHFR A1298C and 559/866 cases/controls for MTRR A66G. The frequencies of the genotypes MTHFR $677 \mathrm{CT}$ and $677 \mathrm{CC}$ were the highest in both cases and controls, and allele $\mathrm{C}$ was the most common. Similarly, the frequencies of the genotypes MTHFR 1298 AC and 1298 AA were the highest in both cases and controls. For MTRR A66G, the 
genotype AG had the highest frequency in both cases and controls, and allele $\mathrm{G}$ was the most common. The genotype distributions and the allele frequencies are shown in Table 2 .

The distribution of genotypes in the control group departs from HWE in one study for MTHFR C677T (Acacio et al. 2005), in one study for MTHFR A1298C (Boduroglu et al. 2004), and in one study for MTRR A66G (Chango et al. 2005). Since a lack of HWE indicates possible genotyping errors and/or population stratification, a sensitivity analysis excluding these studies was therefore carried out; however, the results produced should be interpreted with caution.

Four studies provided data for the combined genotype distribution for MTHFR C677T and MTHFR A1298C polymorphisms (Coppede et al. 2006; Rai et al. 2006; Boduroglu et al. 2004; Acacio et al. 2005), one study provided data for combinations of MTHFR C677T T- carriers (Chango et al. 2005), and one study for combinations of MTHFR C677T homozygous for T (Scala et al. 2006). One study provided data for the combined genotype distribution for MTHFR C677T and MTRR A66G polymorphisms (O'Leary et al. 2002) and two studies provided data for combinations of MTHFR C677T T-carriers (Hobbs et al. 2002; Chango et al. 2005).

Main results, subgroup and sensitivity analyses

Figure 2 and Table 3 show the results for the associations between the different gene polymorphisms and the risk of DS.

The main analysis of the association between C677T allele $\mathrm{T}$ and the risk of DS relative to the allele $\mathrm{C}$ revealed significant heterogeneity $\left(P=0.03, I^{2}=49 \%\right)$ between the 11 studies, and the RE pooled OR was not significant [RE
Fig. 1 Flow chart of retrieved studies and studies excluded, with reasons specified

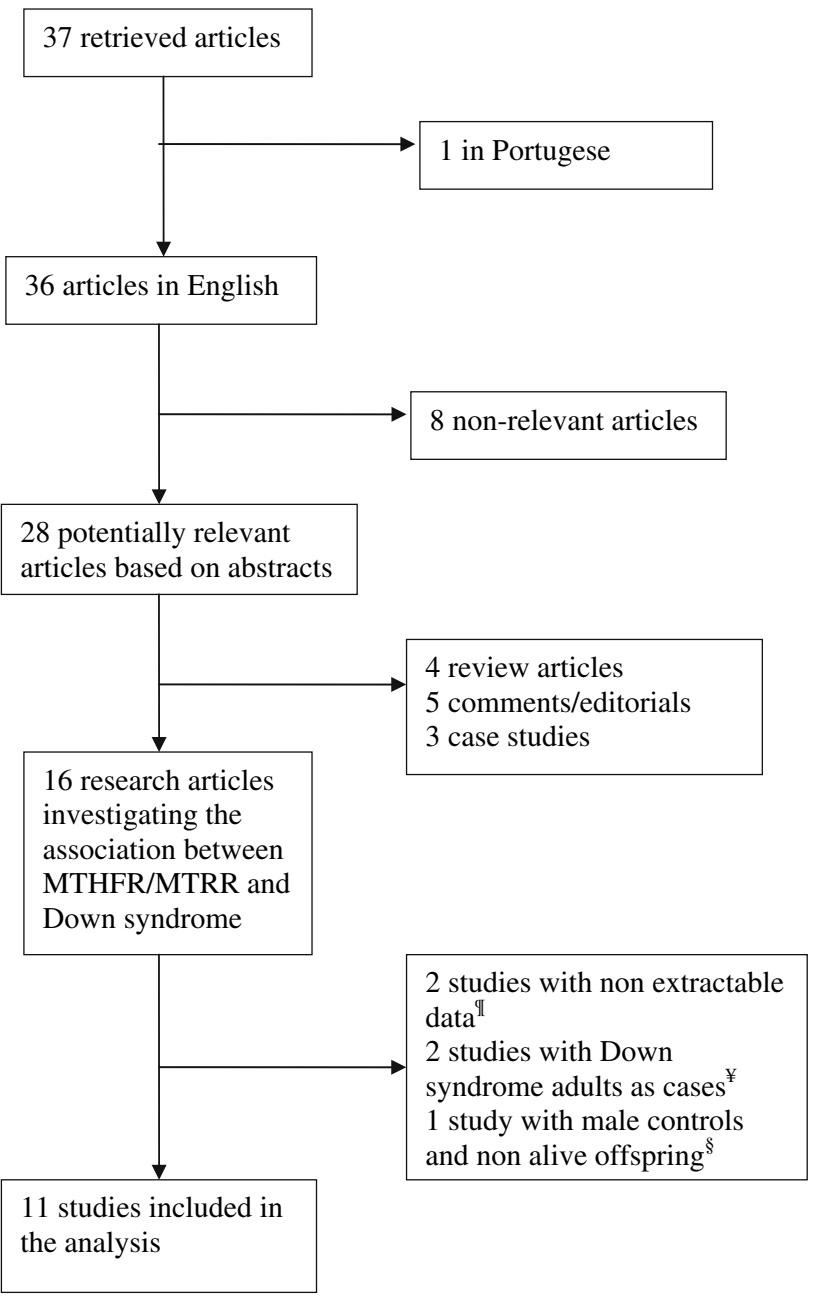

"Martinez-Frias et al., Am J Med Genet A, 2006, 140(9):987-97; Takamura et al., Eur J Nutr, 2004, 43(5):285-7. ${ }^{¥}$ Fillon-Emery et al., Am J Clin Nutr, 2004, 80(6):1551-7; Bosco et al., 2003, Am J Med Genet A, 2003, 121(3):219-24. ${ }^{8}$ Chadefaux-Vekemans et al., Pediatr Res, 2002, 51(6):766-7 
Table 1 Characteristics of the eligible studies considered in the meta-analysis

\begin{tabular}{|c|c|c|c|c|}
\hline References & "Race" & $\begin{array}{l}\text { Polymorphisms studied } \\
\text { and included in } \\
\text { meta-analysis }\end{array}$ & $\begin{array}{l}\text { Selection and characteristics } \\
\text { of cases with Down } \\
\text { syndrome (DS) }\end{array}$ & $\begin{array}{l}\text { Selection and characteristics } \\
\text { of controls }\end{array}$ \\
\hline James et al. (1999) & Whites & MTHFR C677T & $\begin{array}{l}57 \text { Mothers of children with DS } \\
\text { with age at conception } \\
<40 \text { years }\end{array}$ & $\begin{array}{l}50 \text { Control mothers with no } \\
\text { miscarriages and no abnormal } \\
\text { pregnancies, age-matched }\end{array}$ \\
\hline Hobbs et al. (2000) & Whites & $\begin{array}{l}\text { MTHFR C677T } \\
\text { MTRR A66G }\end{array}$ & $\begin{array}{l}157 \text { DS mothers, no demographics } \\
\text { were reported }\end{array}$ & $\begin{array}{l}94 \text { Control mothers, no } \\
\text { demographics were reported }\end{array}$ \\
\hline Stuppia et al. (2002) & Whites & MTHFR C677T & $\begin{array}{l}64 \text { DS mothers with mean age at } \\
\text { conception: } 30.9 \text { years (range } \\
20-46 \text { ), } 78 \% \text { aged }<35 \text { years }\end{array}$ & $\begin{array}{l}112 \text { Control mothers with } \\
\text { unremarkable pregnancy, } \\
\text { age-matched }\end{array}$ \\
\hline O’Leary et al. (2002) & Whites & $\begin{array}{l}\text { MTHFR C677T } \\
\text { MTRR A66G }\end{array}$ & $\begin{array}{l}48 \text { DS mothers, demographics } \\
\text { were not reported }\end{array}$ & $\begin{array}{l}192 \text { Control mothers who } \\
\text { delivered unaffected infants, } \\
\text { demographics were not reported }\end{array}$ \\
\hline Boduroglu et al. (2004) & Turkish & $\begin{array}{l}\text { MTHFR C677T } \\
\text { MTHFR A1298C }\end{array}$ & $\begin{array}{l}152 \text { DS mothers, } 67 \% \text { aged } \\
<35 \text { years, } 93 \% \text { living in urban } \\
\text { area, } 32 \% \text { used multivitamins } \\
\text { irregularly }\end{array}$ & $\begin{array}{l}91 \text { Control mothers who had given } \\
\text { birth to at least two healthy } \\
\text { children without a history of any } \\
\text { miscarriages or abnormal } \\
\text { pregnancy }\end{array}$ \\
\hline Acacio et al. (2005) & $\begin{array}{r}\text { Brazilians } \\
\text { (mixed) }\end{array}$ & $\begin{array}{l}\text { MTHFR C677T } \\
\text { MTHFR A1298C }\end{array}$ & $\begin{array}{l}70 \text { DS mothers with average } \\
\text { maternal age } 25.3 \text { years, } 80 \% \\
\text { whites }\end{array}$ & $\begin{array}{l}88 \text { Control mothers who had never } \\
\text { suffered a miscarriage, maternal } \\
\text { age } 31.3 \text { years, } 58 \% \text { whites }\end{array}$ \\
\hline Chango et al. (2005) & Whites & $\begin{array}{l}\text { MTHFR C677T } \\
\text { MHFR A1298C } \\
\text { MTRR A66G }\end{array}$ & $\begin{array}{l}190 \text { DS mothers with age when } \\
\text { giving birth: } 33.8 \pm 6 \text { years }\end{array}$ & $\begin{array}{l}119 \text { Control mothers who had } \\
\text { never given birth to children } \\
\text { with congenital abnormalities, } \\
\text { age when giving birth: } \\
29.5 \pm 6 \text { years }\end{array}$ \\
\hline da Silva et al. (2005) & $\begin{array}{r}\text { Brazilians } \\
\text { (mixed) }\end{array}$ & $\begin{array}{l}\text { MTHFR C677T } \\
\text { MHFR A1298C } \\
\text { MTRR A66G }\end{array}$ & $\begin{array}{l}154 \text { DS mothers, } 64 \% \text { with age } \\
\text { under } 34 \text { years at the time of } \\
\text { delivery }\end{array}$ & $\begin{array}{l}158 \text { Control mothers with no } \\
\text { previous affected child and with } \\
\text { no conditions linked to } \\
\text { hyperhomocysteinemia, } 90 \% \\
\text { with age under } 34 \text { years at the } \\
\text { time of delivery, matched by } \\
\text { racial background and } \\
\text { sociodemographic } \\
\text { characteristics }\end{array}$ \\
\hline Rai et al. (2006) & Indians & $\begin{array}{l}\text { MTHFR C677T } \\
\text { MTHFR A1298C }\end{array}$ & $\begin{array}{l}149 \text { DS mothers with mean } \\
\text { maternal age } 27.4 \pm 6.7 \text { years } \\
(68 \% \text { aged }<31 \text { years })\end{array}$ & $\begin{array}{l}165 \text { Control mothers with normal } \\
\text { children and no reported } \\
\text { abnormalities, mean age: } \\
26.8 \pm 8 \text { years }\end{array}$ \\
\hline Scala et al. (2006) & Whites & $\begin{array}{l}\text { MTHFR C677T } \\
\text { MHFR A1298C } \\
\text { MTRR A66G }\end{array}$ & $\begin{array}{l}94 \text { DS mothers with mean age at } \\
\text { conception: } 32.4 \pm 6.3 \text { years }\end{array}$ & $\begin{array}{l}264 \text { Healthy control mothers with } \\
\text { mean age at conception in last } \\
\text { pregnancy: } 32.4 \pm 6.3 \text { years }\end{array}$ \\
\hline Coppede et al. (2006) & Whites & $\begin{array}{l}\text { MHTFR C677T } \\
\text { MTHFR A1298C }\end{array}$ & $\begin{array}{l}80 \text { DS mothers, }<35 \text { years at } \\
\text { conception (mean age } \\
28.4 \pm 4.5 \text { years) }\end{array}$ & $\begin{array}{l}111 \text { Control mothers with at least } \\
\text { one healthy child and no } \\
\text { experience of miscarriages or } \\
\text { abnormal pregnancies, age- } \\
\text { matched at conception }\end{array}$ \\
\hline
\end{tabular}

$\mathrm{OR}=1.18(0.99-1.40)]$. In subgroup analysis, whites also produced a nonsignificant association $[\mathrm{RE} \mathrm{OR}=1.04$ $(0.83-1.30)]$. The recessive model for allele $\mathrm{T}$ showed nonsignificant heterogeneity overall $\left(P=0.21, I^{2}=24 \%\right)$ and in whites $\left(P=0.73, I^{2}=0 \%\right)$, and the associations were not significant: FE OR $=1.27(0.98-1.64)$ and FE $\mathrm{OR}=1.08 \quad(0.80-1.45), \quad$ respectively. However, the sensitivity analysis (exclusion of study with controls not in HWE) changed the pattern of results overall, and the association became marginally significant $[\mathrm{FE}$ OR $=1.31$ (1.01-1.71) $, P=0.21, I^{2}=26 \%$ ]. The dominant model showed a lack of heterogeneity and no association.

For the A1298C polymorphism and its association with DS, the allele contrast $\mathrm{C}$ versus A showed significant 
Table 2 The distributions of (a) MTHFR C677T, (b) MTHFR A1298C and (c) MTRR A66G genotypes and allele frequencies for DS (cases) and controls (the respective percentages are in parentheses)

\begin{tabular}{|c|c|c|c|c|c|c|c|c|c|c|}
\hline \multirow{3}{*}{$\begin{array}{l}\text { All studies } \\
\text { References }\end{array}$} & \multicolumn{6}{|c|}{ (a) Distribution of MTHFR C677T genotype } & \multicolumn{4}{|c|}{ Frequency of MTHFR C677T alleles } \\
\hline & \multicolumn{2}{|l|}{ TT } & \multicolumn{2}{|l|}{$\mathrm{CT}$} & \multicolumn{2}{|l|}{$\mathrm{CC}$} & \multicolumn{2}{|l|}{$\mathrm{T}$} & \multicolumn{2}{|c|}{$\mathrm{C}$} \\
\hline & Cases & Controls & Cases & Controls & Cases & Controls & Cases & Controls & Cases & Controls \\
\hline James et al. (1999) & $4(8)$ & $8(14)$ & $22(44)$ & $34(59)$ & $24(48)$ & $15(26)$ & $30(30)$ & $50(43)$ & $70(70)$ & $64(56)$ \\
\hline Hobbs et al. (2000) & $22(14)$ & $14(10)$ & $84(53)$ & $59(42)$ & $51(32)$ & $67(47)$ & $128(40)$ & $87(31)$ & $186(59)$ & $193(68)$ \\
\hline O’Leary et al. (2002) & $2(4)$ & $18(9)$ & $21(51)$ & $84(43)$ & $18(43)$ & $90(46)$ & $25(30)$ & $120(31)$ & 57 (69) & $264(68)$ \\
\hline Stuppia et al. (2002) & $12(18)$ & $23(20)$ & $32(50)$ & $62(55)$ & $20(31)$ & $27(24)$ & $56(43)$ & $108(48)$ & $72(56)$ & $116(51)$ \\
\hline Boduroglu et al. (2004) & $11(7)$ & $3(3)$ & $55(36)$ & $30(32)$ & $86(56)$ & $58(63)$ & $77(25)$ & 36 (19) & $227(74)$ & $146(80)$ \\
\hline Chango et al. (2005) & $12(10)$ & $12(10)$ & $64(53)$ & $58(48)$ & $43(36)$ & $49(41)$ & $88(36)$ & $82(34)$ & $150(63)$ & $156(65)$ \\
\hline da Silva et al. (2005) & $15(9)$ & $7(4)$ & $72(46)$ & $67(42)$ & $67(43)$ & $84(53)$ & $102(33)$ & $81(25)$ & $206(66)$ & $235(74)$ \\
\hline Acacio et al. (2005) & $5(7)$ & $9(10)$ & $30(42)$ & $25(28)$ & $35(50)$ & $54(61)$ & $40(28)$ & $43(24)$ & $100(71)$ & $133(75)$ \\
\hline Coppede et al. (2006) & $16(20)$ & $18(16)$ & $43(54)$ & $54(48)$ & $20(25)$ & $39(35)$ & $75(47)$ & $90(40)$ & $83(52)$ & $132(59)$ \\
\hline Rai et al. (2006) & $12(8)$ & $2(1)$ & $40(26)$ & $39(23)$ & $97(65)$ & $124(75)$ & $64(21)$ & $43(13)$ & $234(78)$ & $287(86)$ \\
\hline Scala et al. (2006) & $24(25)$ & $57(22)$ & $39(41)$ & $125(48)$ & $31(32)$ & $74(28)$ & $87(46)$ & $239(46)$ & $101(53)$ & $273(53)$ \\
\hline Total & $135(11)$ & $171(11)$ & $502(44)$ & $637(42)$ & $492(43)$ & $681(45)$ & $772(34)$ & $979(32)$ & $1,486(65)$ & $1,999(67)$ \\
\hline All studies & \multicolumn{6}{|c|}{ (b) Distribution of MTHFR A1298C genotype } & \multicolumn{4}{|c|}{ Frequency of MTHFR A1298C alleles } \\
\hline \multirow[t]{2}{*}{ References } & \multicolumn{2}{|l|}{$\mathrm{CC}$} & \multicolumn{2}{|l|}{$\mathrm{AC}$} & \multicolumn{2}{|l|}{ AA } & \multicolumn{2}{|l|}{$\mathrm{C}$} & \multicolumn{2}{|l|}{ A } \\
\hline & Cases & Controls & Cases & Controls & Cases & Controls & Cases & Controls & Cases & Controls \\
\hline Boduroglu et al. (2004) & $11(7)$ & $10(10)$ & $97(63)$ & $60(65)$ & $44(28)$ & $21(23)$ & 119 (39) & $80(43)$ & $185(60)$ & $102(56)$ \\
\hline Chango et al. (2005) & $11(9)$ & $12(10)$ & $49(41)$ & $56(46)$ & $59(49)$ & $52(43)$ & $71(29)$ & $80(33)$ & $167(70)$ & $160(66)$ \\
\hline da Silva et al. (2005) & $6(3)$ & $7(4)$ & $49(31)$ & $50(31)$ & $99(64)$ & $101(63)$ & $61(19)$ & $64(20)$ & $247(80)$ & $252(79)$ \\
\hline Acacio et al. (2005) & $30(43)$ & $50(56)$ & $37(53)$ & $32(36)$ & $2(2)$ & $6(6)$ & $97(70)$ & $132(75)$ & $41(29)$ & $44(25)$ \\
\hline Coppede et al. (2006) & $3(4)$ & $6(6)$ & $29(42)$ & $48(48)$ & $37(53)$ & $46(46)$ & $35(25)$ & $60(30)$ & $103(74)$ & $140(70)$ \\
\hline Rai et al. (2006) & $22(24)$ & $5(7)$ & $39(43)$ & $37(52)$ & $28(31)$ & $28(40)$ & $83(46)$ & 47 (33) & $95(53)$ & $93(66)$ \\
\hline Scala et al. (2006) & $17(18)$ & $25(9)$ & $39(41)$ & $108(41)$ & $38(40)$ & $128(49)$ & $73(38)$ & $158(30)$ & $115(61)$ & $364(69)$ \\
\hline Total & $100(13)$ & $115(12)$ & $339(45)$ & $391(44)$ & $307(41)$ & $382(43)$ & $539(36)$ & $621(34)$ & $953(63)$ & $1,155(65)$ \\
\hline All studies & \multicolumn{6}{|c|}{ (c) Distribution of MTRR A66G genotype } & \multicolumn{4}{|c|}{ Frequency of MTRR A66G alleles } \\
\hline \multirow[t]{2}{*}{ References } & \multicolumn{2}{|l|}{ GG } & \multicolumn{2}{|l|}{ AG } & \multicolumn{2}{|l|}{ AA } & \multicolumn{2}{|l|}{ G } & \multicolumn{2}{|l|}{ A } \\
\hline & Cases & Controls & Cases & Controls & Cases & Controls & Cases & Controls & Cases & Controls \\
\hline Hobbs et al. (2000) & $55(37)$ & $32(23)$ & $64(44)$ & $68(48)$ & $26(17)$ & $39(28)$ & $174(60)$ & $132(47)$ & $116(40)$ & $146(52)$ \\
\hline O'Leary et al. (2002) & $24(50)$ & $56(29)$ & $23(47)$ & $101(52)$ & $1(2)$ & $35(18)$ & $71(73)$ & $213(55)$ & $25(26)$ & $171(44)$ \\
\hline Chango et al. (2005) & $48(40)$ & $42(35)$ & $66(55)$ & $72(60)$ & $5(4)$ & $6(5)$ & $162(68)$ & $156(65)$ & $76(31)$ & $84(35)$ \\
\hline da Silva et al. (2005) & $25(16)$ & $26(16)$ & $92(59)$ & $87(55)$ & $37(24)$ & $45(28)$ & $142(46)$ & $139(43)$ & $166(53)$ & $177(56)$ \\
\hline Scala et al. (2006) & $19(20)$ & $57(22)$ & $46(49)$ & $131(50)$ & $28(30)$ & $69(26)$ & $84(45)$ & $245(47)$ & $102(54)$ & $269(52)$ \\
\hline Total & 171 (30) & 213 (24) & $291(52)$ & 459 (53) & 97 (17) & 194 (22) & 633 (56) & 885 (51) & 485 (43) & 847 (48) \\
\hline
\end{tabular}

heterogeneity among studies $\left(P=0.04, I^{2}=56 \%\right)$ and the association was nonsignificant: FE OR $=1.02$ (0.81-1.29). The dominant and recessive models for allele $\mathrm{C}$ produced no significant associations overall, and in whites.

Finally, no statistically significant association between the MTRR A66G gene polymorphism and the risk of DS for the contrasts under investigation was found in any case. In addition, there was significant heterogeneity among studies $(P<0.10)$.
Potential bias

Two studies reported that genotyping was blind with respect to clinical status (James et al. 1999; Hobbs et al. 2000). In cumulative meta-analysis for MTHFR C677T, the allelic contrast showed a trend towards association as the information accumulated, whereas MTHFR A1298C and MTRR A66G showed no such trend (Fig. 3). In recursive cumulative meta-analysis for the allele contrast, 
Fig. 2a-c Random effects $(R E)$ odds ratio $(O R)$ estimates with the corresponding $95 \%$ confidence interval $(C I)$ for the allele contrast of (a) MTHFR $677 \mathrm{~T}$ versus C, (b) MTHFR $1298 \mathrm{C}$ versus A, and (c) MTRR $66 \mathrm{G}$ versus $\mathrm{A}$ and the risk of Down syndrome. The OR estimate for each study is marked with a solid black square. The size of the square represents the weight that the corresponding study exerts in the meta-analysis. The CIs of the pooled estimates are displayed as a horizontal line through the diamond; all of this line might be inside the diamond if the $\mathrm{CI}$ is narrow.

The horizontal axis is plotted on a log scale (a)

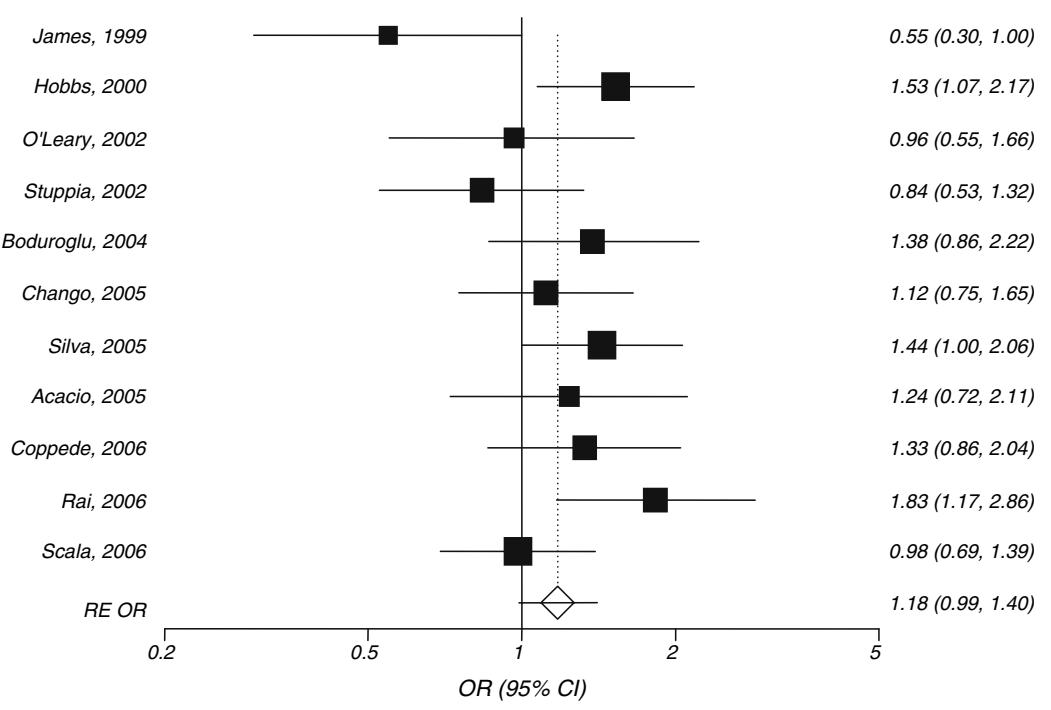

(b)

Boduroglu, 2004

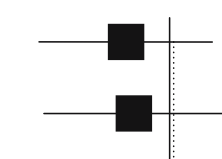

$0.82(0.56,1.21)$

Chango, 2005

Silva, 2005

Acacio, 2005

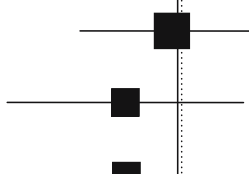

$0.85(0.57,1.27)$

$0.97(0.64,1.47)$

$0.79(0.46,1.34)$

Coppede, 2006

Rai, 2006

Scala, 2006

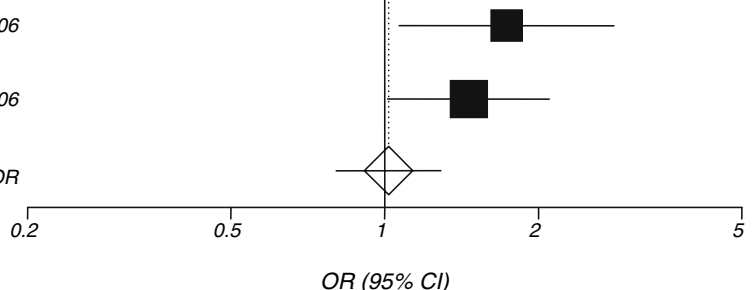

OR $(95 \% \mathrm{Cl})$

(c)

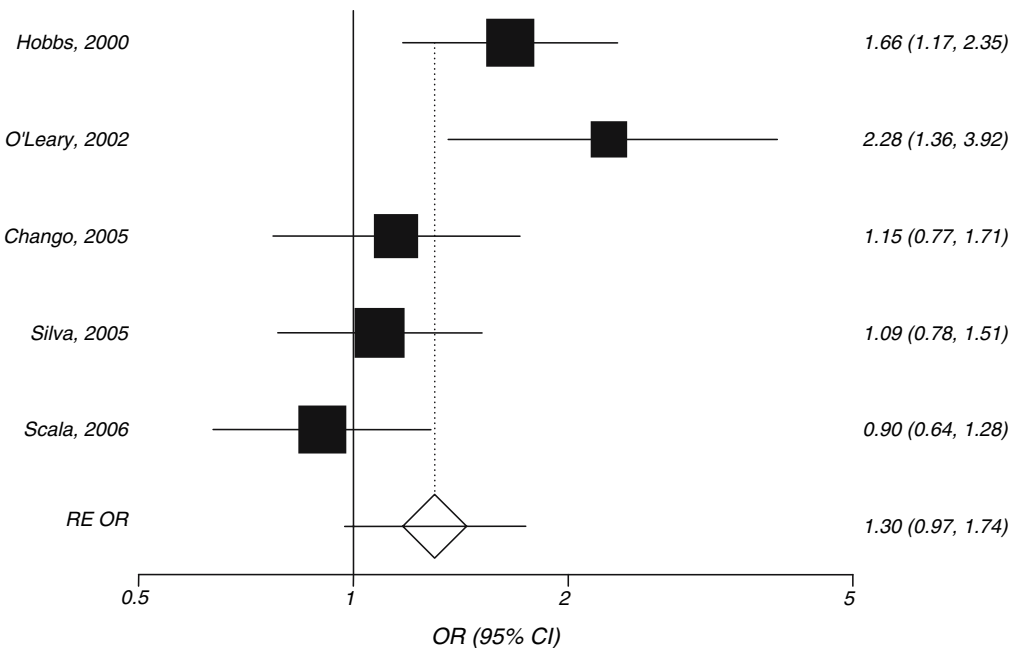


Table 3 Odds ratios and heterogeneity results for the genetic contrasts of (a) MTHFR C677T, (b) MTHFR A1298C, and (c) MTRR A66G gene polymorphisms and DS

$\begin{array}{lllll}\text { Population } & \text { Fixed effects OR }(95 \% \mathrm{CI}) & \text { Random effects OR (95\% CI) } & I^{2}(\%) & P \text { value } \\ Q \text { test }\end{array}$

\begin{tabular}{|c|c|c|c|c|c|}
\hline \multicolumn{6}{|c|}{ (a) Contrast for C677T } \\
\hline \multirow[t]{3}{*}{$\mathrm{T}$ versus $\mathrm{C}$} & All & $1.20(1.06-1.35)$ & $1.18(0.99-1.40)$ & 49 & 0.03 \\
\hline & All in HWE & $1.20(1.05-1.36)$ & $1.17(0.97-1.42)$ & 54 & 0.02 \\
\hline & Whites & $1.07(0.92-1.25)$ & $1.04(0.83-1.30)$ & 51 & 0.06 \\
\hline \multirow[t]{3}{*}{ Recessive model } & All & $1.27(0.98-1.64)$ & $1.24(0.90-1.70)$ & 24 & 0.21 \\
\hline & All in HWE & $1.31(1.01-1.71)$ & $1.29(0.93-1.80)$ & 26 & 0.21 \\
\hline & Whites & $1.08(0.80-1.45)$ & $1.09(0.81-1.47)$ & 0 & 0.73 \\
\hline \multirow[t]{3}{*}{ Dominant model } & All & $1.26(1.07-1.49)$ & $1.22(0.96-1.55)$ & 48 & 0.04 \\
\hline & All in HWE & $1.24(1.04-1.47)$ & $1.19(0.92-1.54)$ & 52 & 0.03 \\
\hline & Whites & $1.11(0.89-1.38)$ & $1.04(0.72-1.51)$ & 63 & 0.01 \\
\hline \multicolumn{6}{|c|}{ (b) Contrast for A1298C } \\
\hline \multirow[t]{3}{*}{$\mathrm{C}$ versus $\mathrm{A}$} & All & $1.03(0.88-1.20)$ & $1.02(0.81-1.29)$ & 56 & 0.04 \\
\hline & All in HWE & $1.08(0.91-1.28)$ & $1.06(0.81-1.38)$ & 58 & 0.04 \\
\hline & Whites & $1.05(0.84-1.32)$ & $1.02(0.68-1.52)$ & 66 & 0.05 \\
\hline \multirow[t]{3}{*}{ Recessive model } & All & $1.11(0.81-1.52)$ & $1.10(0.63-1.91)$ & 63 & 0.01 \\
\hline & All in HWE & $1.20(0.85-1.67)$ & $1.21(0.65-2.26)$ & 66 & 0.01 \\
\hline & Whites & $1.36(0.83-2.23)$ & $1.29(0.66-2.50)$ & 37 & 0.21 \\
\hline \multirow[t]{3}{*}{ Dominant model } & All & $1.00(0.81-1.25)$ & $1.00(0.78-1.28)$ & 18 & 0.29 \\
\hline & All in HWE & $1.05(0.84-1.33)$ & $1.05(0.81-1.38)$ & 19 & 0.29 \\
\hline & Whites & $0.98(0.73-1.32)$ & $0.96(0.62-1.47)$ & 49 & 0.14 \\
\hline \multicolumn{6}{|c|}{ (c) Contrast for A66G } \\
\hline \multirow[t]{3}{*}{$\mathrm{G}$ versus $\mathrm{A}$} & All & $1.26(1.08-1.48)$ & $1.30(0.97-1.74)$ & 69 & 0.01 \\
\hline & All in HWE & $1.28(1.08-1.53)$ & $1.35(0.93-1.96)$ & 76 & 0.01 \\
\hline & Whites & $1.33(1.10-1.60)$ & $1.38(0.94-2.01)$ & 75 & 0.01 \\
\hline \multirow[t]{3}{*}{ Recessive model } & All & $1.40(1.09-1.80)$ & $1.40(0.97-2.04)$ & 53 & 0.07 \\
\hline & All in HWE & 1.45 (1.09-1.93) & $1.45(0.89-2.35)$ & 64 & 0.04 \\
\hline & Whites & $1.51(1.15-1.99)$ & $1.53(1.00-2.34)$ & 56 & 0.08 \\
\hline \multirow[t]{3}{*}{ Dominant model } & All & $1.37(1.03-1.83)$ & $1.36(0.85-2.17)$ & 51 & 0.09 \\
\hline & All in HWE & $1.38(1.03-1.86)$ & $1.42(0.82-2.45)$ & 63 & 0.04 \\
\hline & Whites & $1.43(1.01-2.02)$ & $1.50(0.74-3.05)$ & 63 & 0.04 \\
\hline
\end{tabular}

the relative change in RE OR did not stabilize in a specific OR, indicating that there was insufficient evidence for claiming or denying an association (Fig. 4). The Egger test and the Begg-Mazumdar test for the allele contrast MTHFR $677 \mathrm{~T}$ versus $\mathrm{C}$ indicated that there was no difference in magnitude of effect in large versus small studies ( $P=0.17$ and $P=0.16$, respectively).

\section{Discussion}

This meta-analysis examined the MTHFR C677T, MTHFR A1298C and MTRR A66G gene polymorphisms and their relationship to the risk of developing DS. The strength of the present analysis was based on an accumulation of published data, providing greater information to detect significant differences. In the present study the effect of allele frequency and the effects of the dominant and recessive models were estimated. In the main analysis and in whites, the allele contrast, the recessive and the dominant models for each gene polymorphism produced nonsignificant results, and heterogeneity ranged from none to high. However, the pooled OR of the meta-analysis excluded with $95 \%$ certainty that carriers of the MTHFR $677 \mathrm{~T}$ allele would have more than 1.64-fold increased odds of maternal DS. In addition, sensitivity analysis for the recessive model in MTHFR C677T produced a marginally significant association, but the result produced should be interpreted with caution.

The overall lack of association between MTHFR C677T, MTHFR A1298C and MTRR A66G gene polymorphisms and DS may be due to other gene polymorphisms involved 


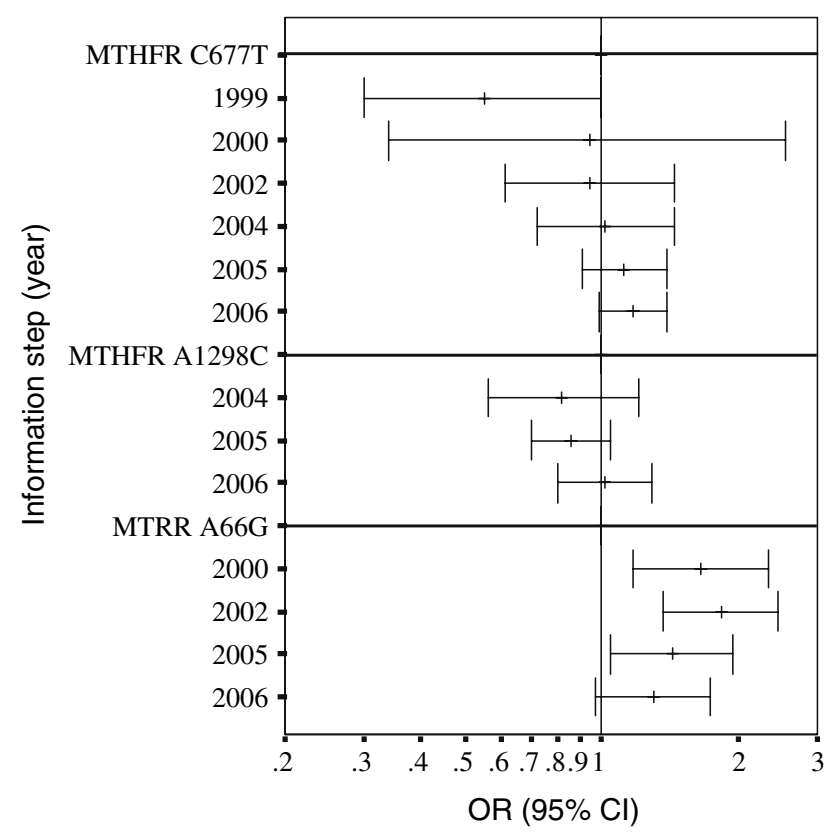

Fig. 3 Cumulative meta-analysis: the RE pooled OR with the corresponding $95 \% \mathrm{CI}$ at the end of each year information step is shown

in the homocysteine and folate metabolic pathway that affect the risk of developing DS (James et al. 1999; da Silva et al. 2005). However, the interaction of the gene polymorphisms could be a major determinant of disease risk rather than the individual polymorphisms (Hobbs et al. 2000). Thus, individual gene polymorphism genotypes might not be reliable markers of risk for developing DS. Therefore, a meta-analysis of genotype combinations may provide more reliable information than single gene polymorphisms (Zintzaras et al. 2006a). In the present metaanalysis, there were not enough data to perform such an analysis. In addition, the lack of association between the studied gene polymorphisms and DS might be due to other unidentified loci that are probably in linkage disequilibrium and affect the risk of developing DS. Risk effect may depend on gene methylation, and thus gene-environment interactions between the genotypes and dietary intake, and in particular folic acid consumption, may be crucial to maintaining or altering the effects of the polymorphic variants (Martinez-Frias et al. 2006).

Sampling variability and stratification in case-control study design can be a possible confounding factor in the role of genetic markers. In addition, age can be an independent risk factor associated with increased rates of DS (Scala et al. 2006). Thus, the absence of maternal DS in young mothers does not exclude the possibility of DS later. In many studies the controls were not matched and young mothers were frequently included as controls. Therefore, a control group may include cases that are still at risk of

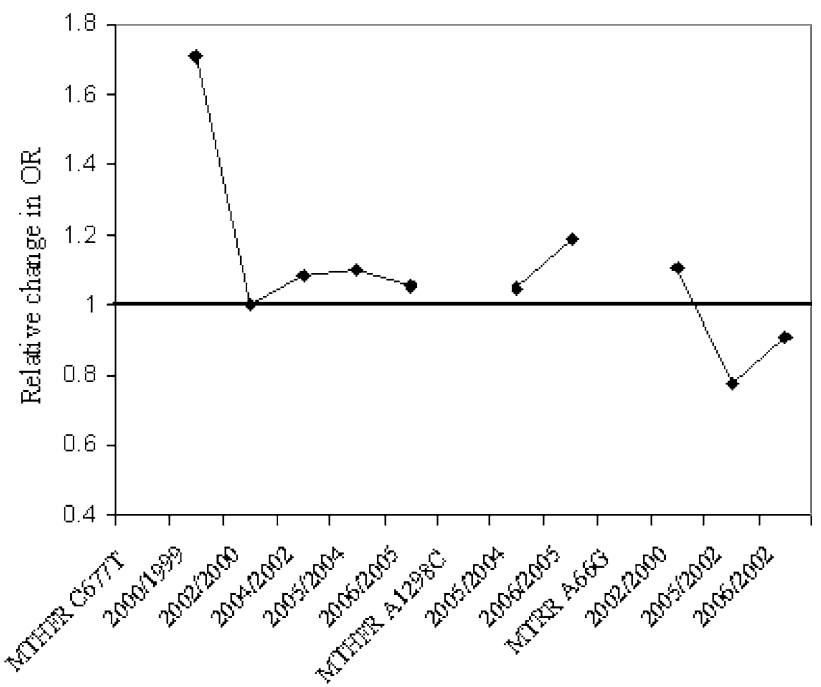

Fig. 4 Recursive cumulative meta-analysis: the relative change in $\mathrm{RE}$ pooled OR in each information step (OR in the next year/OR in current year) is shown

maternal DS. A meta-analysis considering the effect of age on the association between gene polymorphisms and DS can provide more conclusive evidence; however, such data were not available in the published literature.

Population diversity may influence the genetic effects of complex diseases in a meta-analysis. Although there is controversy regarding the categorization of populations by "race" (Jorde and Wooding 2004; Collins 2004), there is evidence that individuals can be grouped into three main groups (Ioannidis et al. 2004; Jorde and Wooding 2004) according to geographical origin or ancestry: (1) whites (including populations of European descent from Oceania, North America and South America), (2) sub-Saharan Africans (including African-Americans), and (3) East Asians (populations from China, Japan, Korea, Indochina and Philippines). Human genetic variation is distributed in a continuous manner, and populations are genetically impure, and so the definition of boundaries between "races" may be arbitrary. Moreover, the consistency of genetic effects across traditionally defined "racial" groups does not necessarily mean that "race"-specific genetic effects are exactly the same (Ioannidis et al. 2004).

For most meta-analysis applications in genetics/ genomics, the sample sizes of individual studies tend to be small. The power of single studies is usually very low. A combination of low power and high biological multiplicity results is expected to result in a very high false discovery rate (Ioannidis 2005). The synthesis of data from many studies is expected to improve power and reduce false discovery rate in all circumstances and so the gain could be considerable, unless there is a very large genuine betweenstudy heterogeneity (Hedges and Pigott 2001). However, 
power calculations are usually considered inappropriate in meta-analysis, since those data are already assembled.

There is no indication of potential bias in the metaanalysis; however, the estimates from the studies of MTHFR C677T allelic contrast showed alteration of early extreme findings in short sequences. This phenomenon occurs when large numbers of studies performed in a limited time and new research findings with extreme effects are published more rapidly (Zintzaras et al. 2006a). Studies can often give very different results and exploratory, hypothesis-generating findings may not be replicated across several studies. The meta-analysis showed a large heterogeneity between studies, which may be due to genuine differences in the studied populations and to differences in study design and conduct. In a meta-analysis of genetic association studies, the quantification and explanation of the observed heterogeneity between studies is probably more important than simply generating summary estimates from the combined data (Lau et al. 1998). When heterogeneity between studies exists, the results should be interpreted in the context of cumulative and recursive cumulative meta-analysis (Lau et al. 1992). When investigating MTHFR C677T gene polymorphism and DS, the cumulative meta-analysis showed a trend towards a significant association and the recursive cumulative meta-analysis showed fluctuations since the relative change in OR did not stabilize. Thus, it is evident that existing research cannot establish the importance of the association, and more evidence is required or the metaanalysis criteria should be changed to obtain a more homogeneous set of studies.

In summary, the accumulated evidence has indicated a lack of association between MTHFR C677T, MTHFR A1298C and MTRR A66G gene polymorphisms and maternal DS. The results of the present meta-analysis were based on relatively small numbers of studies and participants, and must be interpreted with caution. The relationship between DS and the gene polymorphisms involved in the homocysteine/folate metabolism remains an unresolved issue. Large and rigorous case-control studies that investigate combinations of gene polymorphisms (Chango et al. 2005) and gene-environment interactions (Clayton and McKeigue 2001) need to be performed before conclusive claims about the genetics of DS can be made.

\section{References}

Antonarakis SE, Petersen MB, McInnis MG, Adelsberger PA, Schinzel AA, Binkert F, Pangalos C, Raoul O, Slaugenhaupt SA, Hafez M (1992) The meiotic stage of nondisjunction in trisomy 21: determination by using DNA polymorphisms. Am J Hum Genet 50:544-550
Acacio GL, Barini R, Bertuzzo CS, Couto EC, Annichino-Bizzacchi JM, Junior WP (2005) Methylenetetrahydrofolate reductase gene polymorphisms and their association with trisomy 21. Prenat Diagn 25:1196-1199

Begg CB, Mazumdar M (1994) Operating characteristics of a rank correlation test for publication bias. Biometrics 50:1088-1101

Blount BC, Mack MM, Wehr CM, MacGregor JT, Hiatt RA, Wang G, Wickramasinghe SN, Everson RB, Ames BN (1997) Folate deficiency causes uracil misincorporation into human DNA and chromosome breakage: implications for cancer and neuronal damage. Proc Natl Acad Sci USA 7:3290-3295

Boduroglu K, Alanay Y, Koldan B, Tuncbilek E (2004) Methylenetetrahydrofolate reductase enzyme polymorphisms as maternal risk for Down syndrome among Turkish women. Am J Med Genet A 127:5-10

Chango A, Fillon-Emery N, Mircher C, Blehaut H, Lambert D, Herbeth B, James SJ, Rethore MO, Nicolas JP (2005) No association between common polymorphisms in genes of folate and homocysteine metabolism and the risk of Down's syndrome among French mothers. Br J Nutr 94:166-169

Clayton D, McKeigue PM (2001) Epidemiological methods for studying genes and environmental factors in complex diseases. Lancet 358:1356-1360

Cochran WG (1954) The combination of estimates from different experiments. Biometrics 10:101-129

Collins FS (2004) What we do and don't know about 'race', 'ethnicity', genetics and health at the dawn of the genome era. Nat Genet 36:S13-S15

Coppede F, Marini G, Bargagna S, Stuppia L, Minichilli F, Fontana I, Colognato R, Astrea G, Palka G, Migliore L (2006) Folate gene polymorphisms and the risk of Down syndrome pregnancies in young Italian women. Am J Med Genet A 140:1083-1091

da Silva LR, Vergani N, Galdieri Lde C, Ribeiro Porto MP, Longhitano SB, Brunoni D, D'Almeida V, Alvarez Perez AB (2005) Relationship between polymorphisms in genes involved in homocysteine metabolism and maternal risk for Down syndrome in Brazil. Am J Med Genet A 135:263-267

Frosst P, Blom HJ, Milos R, Goyette P, Sheppard CA, Matthews RG, Boers GJ, den Heijer M, Kluijtmans LA, van den Heuvel LP (1995) A candidate genetic risk factor for vascular disease: a common mutation in methylenetetrahydrofolate reductase. Nat Genet 10:111-113

Hassold TJ, Jacobs PA (1984) Trisomy in man. Annu Rev Genet 18:69-97

Hedges LV, Pigott DP (2001) The power of statistical tests in metaanalysis. Psychol Methods 6:203-217

Hobbs CA, Sherman SL, Yi P, Hopkins SE, Torfs CP, Hine RJ, Pogribna M, Rozen R, James SJ (2000) Polymorphisms in genes involved in folate metabolism as maternal risk factors for Down syndrome. Am J Hum Genet 67:623-630

Hobbs CA, Cleves MA, Lauer RM, Burns TL, James SJ (2002) Preferential transmission of the MTHFR $677 \mathrm{~T}$ allele to infants with Down syndrome: implications for a survival advantage. Am J Med Genet 113:9-14

Ioannidis JPA (2005) Why most published research findings are false. PLoS Med 2:e124

Ioannidis JP, Ntzani EE, Trikalinos TA (2004) 'Racial' differences in genetic effects for complex diseases. Nat Genet 36:1312-1318

James SJ (2004) Maternal metabolic phenotype and risk of Down syndrome: beyond genetics. Am J Med Genet A 127:1-4

James SJ, Pogribna M, Pogribny IP, Melnyk S, Hine RJ, Gibson JB, Yi P, Tafoya DL, Swenson DH, Wilson VL, Gaylor DW (1999) Abnormal folate metabolism and mutation in the methylenetetrahydrofolate reductase gene may be maternal risk factors for Down syndrome. Am J Clin Nutr 70:495-501 
Jorde LB, Wooding SP (2004) Genetic variation, classification and 'race'. Nat Genet 36:S28-S33

Kitsios G, Zintzaras E (2007) Genetic variation associated with ischemic heart failure: a HuGE review and meta-analysis. Am J Epidemiol 166(6):619-633

Lau J, Antman EM, Jimenez-Silva J, Kupelnick B, Mosteller F, Chalmers TC (1992) Cumulative meta-analysis of therapeutic trials for myocardial infarction. N Engl J Med 327:248-254

Lau J, Ioannidis JP, Schmid CH (1998) Summing up evidence: one answer is not always enough. Lancet 351:123-127

Martinez-Frias ML, Perez B, Desviat LR, Castro M, Leal F, Rodriguez L, Mansilla E, Martinez-Fernandez ML, Bermejo E, RodriguezPinilla E, Prieto D, Ugarte M (2006) Maternal polymorphisms 677C-T and 1298A-C of MTHFR, and 66A-G MTRR genes: is there any relationship between polymorphisms of the folate pathway, maternal homocysteine levels, and the risk for having a child with Down syndrome? Am J Med Genet A 140:987-997

O'Leary VB, Parle-McDermott A, Molloy AM, Kirke PN, Johnson Z, Conley M, Scott JM, Mills JL (2002) MTRR and MTHFR polymorphism: link to Down syndrome? Am J Med Genet 107:151-155

Rai AK, Singh S, Mehta S, Kumar A, Pandey LK, Raman R (2006) MTHFR C677T and A1298C polymorphisms are risk factors for Down's syndrome in Indian mothers. J Hum Genet 51:278-283

Scala I, Granese B, Sellitto M, Salome S, Sammartino A, Pepe A, Mastroiacovo P, Sebastio G, Andria G (2006) Analysis of seven maternal polymorphisms of genes involved in homocysteine/ folate metabolism and risk of Down syndrome offspring. Genet Med 8:409-416

Sterne JA, Gavaghan D, Egger M (2000) Publication and related bias in meta-analysis: power of statistical tests and prevalence in the literature. J Clin Epidemiol 53:1119-1129

Stuppia L, Gatta V, Gaspari AR, Antonucci I, Morizio E, Calabrese G, Palka G (2002) C677T mutation in the 5,10-MTHFR gene and risk of Down syndrome in Italy. Eur J Hum Genet 10:388390

Ueland PM, Hustad S, Schneede J, Refsum H, Vollset SE (2001) Biological and clinical implications of the MTHFR C677T polymorphism. Trends Pharmacol Sci 22:195-201

Weir BS (1996) Genetic data analysis II: methods for discrete population genetic data. Sinauer Associates, Sunderland, MA

Weisberg I, Tran P, Christensen B, Sibani S, Rozen R (1998) A second genetic polymorphism in methylenetetrahydrofolate reductase (MTHFR) associated with decreased enzyme activity. Mol Genet Metab 64:169-172

Whitehead A (2002) Meta-analysis of controlled clinical trials. Wiley, Chichester, UK

Wilson A, Platt R, Wu Q, Leclerc D, Christensen B, Yang H, Gravel RA, Rozen R (1999) A common variant in methionine synthase reductase combined with low cobalamin (vitamin B12) increases risk for spina bifida. Mol Genet Metab 67:317-323

Zintzaras E (2006a) Association of methylenetetrahydrofolate reductase (MTHFR) polymorphisms with genetic susceptibility to gastric cancer: a meta-analysis. J Hum Genet 51:618-624

Zintzaras E (2006b) C677T and A1298C methylenetetrahydrofolate reductase gene polymorphisms in schizophrenia, bipolar disorder and depression: a meta-analysis of genetic association studies. Psychiatr Genet 16:105-115

Zintzaras E (2006c). Methylenetetrahydrofolate reductase gene and susceptibility to breast cancer: a meta-analysis. Clin Genet 69:327-336

Zintzaras E (2007) Brain-derived neurotrophic factor gene polymorphisms and schizophrenia: a meta-analysis. Psychiatr Genet 17:69-75

Zintzaras E, Hadjigeorgiou GM (2004) Association of paraoxonase 1 gene polymorphisms with risk of Parkinson's disease: a metaanalysis. J Hum Genet 49:474-481

Zintzaras E, Stefanidis I (2005) Association between the GLUT1 gene polymorphism and the risk of diabetic nephropathy: a metaanalysis. J Hum Genet 50:84-91

Zintzaras E, Sakelaridis N (2007) Is 472G/A catechol- $O$-methyltransferase gene polymorphism related to panic disorder? Psychiatr Genet 17:267-273

Zintzaras E, Chatzoulis DZ, Karabatsas CH, Stefanidis I (2005) The relationship between C677T methylenetetrahydrofolate reductase gene polymorphism and retinopathy in type 2 diabetes: a meta-analysis. J Hum Genet 50:267-275

Zintzaras E, Koufakis T, Ziakas PD, Rodopoulou P, Giannouli S, Voulgarelis M (2006a) A meta-analysis of genotypes and haplotypes of methylenetetrahydrofolate reductase gene polymorphisms in acute lymphoblastic leukemia. Eur J Epidemiol 21:501-510

Zintzaras E, Kitsios G, Stefanidis I (2006b) Endothelial NO synthase gene polymorphisms and hypertension: a meta-analysis. Hypertension 48:700-710

Zintzaras E, Stefanidis I, Santos M, Vidal F (2006c) Do alcoholmetabolizing enzyme gene polymorphisms increase the risk of alcoholism and alcoholic liver disease? Hepatology 43:352-361

Zintzaras E, Rodopoulou P, Koukoulis GN (2006d) BsmI, TaqI, ApaI and FokI polymorphisms in the vitamin D receptor (VDR) gene and the risk of osteoporosis: a meta-analysis. Dis Markers $22: 317-326$

Zintzaras E, Uhlig K, Koukoulis GN, Papathanasiou AA, Stefanidis I (2007) Methylenetetrahydrofolate reductase gene polymorphism as a risk factor for diabetic nephropathy: a meta-analysis. J Hum Genet DOI: 10.1007/s10038-007-0189-3 